\section{STOCKHOLM TO SPITSBERGEN: THE GEOLOGISTS' PILGRIMAGE.}

$W^{\mathrm{E}}$ geologists who were privileged to take part in the journey to Spitsbergen before the meeting of the Geological Congress in Stockholm had good reason to count ourselves fortunate. Perfect weather, genial companionship, comfortable surroundings, admirable organisation and guidance, and a route through the strongholds of Thor of the Hammer, in which intense scientific interest was constantly united with entrancing beauty of scenesurely the combination would have roused enthusiasm among much more stolid folk than the impressionable race of hammerers!

We started by special train from Stockholm, about seventy strong, an agglomerate of fifteen nationalities, on the evening of July $\mathbf{2 5}$, and at once left behind us the broken weather that has encircled Western Europe this summer, entering a northern region of brightness and calm in which we continued until our return. Those of us who were in Stockholm the previous day had been called together to see a fine exhibition illustrative of Spitsbergen geology, temporarily shown in rooms attached to the museum of the Swedish Geological Survey, and to hear lucid demonstrations on the exhibits by Prof. A. G. Nathorst and by the Director of our excursion, Prof. G. De Geer. Here we had already an opportunity to begin or to renew friendships that were cemented during the journey. Owing to the care and forethought with which every detail of the expedition had been planned, our start was made promptly, and we settled without confusion into our allotted places.

The night's train journey brought us to Ragunda in Angermanland, where our first halt was made. During four hours of the morning we visited sections splendidly illustrating the evidence from which Prof. De Geer has worked out the chronology of post-Glacial time in Sweden. By a catastrophe in I795, the great lake of Ragunda was suddenly drained and its bed laid bare; and the ravines subsequently eroded through its sediments now reveal the whole succession deposited since the melting of the Glacial ice-sheet. In these sediments Prof. De Geer recognises and counts the annual bands of the "seasonal clays," much as one may count the annual bands in a tree trunk. By the extension of the same method over various other parts of the country, he has attained results by which the recession of the ice-sheet and all its incidents may be actually dated, as he showed us later in field demonstrations near Stockholm during the sitting of the congress.

Northward again for the rest of the day and through a night of twilight, during which the Arctic circle was crossed, our train brought us to breakfast on July 27 at the bright town of Kiruna, which has newly sprung up in the Lapland wilderness under the famous mountain of iron ore. Here we remained until the afternoon, visiting the great iron quarries under the guidance of Director $\mathrm{Hj}$. Lundbohm, who instructed us by a preliminary address in the geology of the district and the history of its rapid development. After a banquet to which we were invited by the mining company we took train again at 4 p.m., and ran shortly into view of the beautiful Lake Torneträsk, in a region of powerful overthrust faults and of Glacial lake-shores. Making several short halts in this wild country to examine points of especial interest within easy reach of the railway, under the guidance of Dr. O. Sjögren, we reached Abisko in the evening. Here our train remained for the night, affording us opportunity to appreciate the picturesque surroundings of Abiskojokk, now a much visited tourist resort.

On the morning of July 28 the Norwegian frontier was reached at II a.m. Thereafter followed a marvellous descent to the coast, along the rim of a great fiord the blue waters of which shone gloriously in the depths below us. At Narvik, our port of embarkation, we were shown the methods of treating the iron ore from Kiruna and the facilities afforded for its shipment, being thereby still further impressed with the enterprise which has been shown in the development of this great Swedish mining industry.

Our ship was the Aolus, Captain S. de Klinteberg, a comfortable Stockholm passenger boat of 870 tons register. Sailing from Narvik at 5 p.m., we were held up for a few hours of the night by fog in the narrow passages leading northward from the Ofoten Fiord; but this was our only delay in the charming voyage to Tromso, which was reached next evening.

There had been rumours of unusual ice conditions in the Spitsbergen seas before we left Stockholm, and at Tromso these rumours were partly confirmed. Our Director, therefore, learning that a French ship was due to arrive next day from the north, decided to await her coming in order to gain definite information. So we spent a calm, sunny day pleasantly at Tromso, first visiting the museum with its excellent collection of Arctic animals and birds, and afterwards crossing to the mainland to see the. Lapp summer camp or to climb the nearer mountains. Meantime the Ile de France had arrived, and reported that while floe-ice from Barents Sea had drifted in quantity round the south and south-west coast of Spitsbergen, the inner fiords of the island were free, so that the only difficulty was to obtain access to them, for which purpose it might be necessary to go far to the westward. With this intelligence we steamed ahead again on the evening of July 30.

As we passed northward in the shadow of the fiords a red glow of wonderful brilliancy shone on all the higher peaks and glaciers, and never faded; until, at midnight, as we passed out into the open ocean under the majestic Fugle Rock, we saw the disc of the sun just cut by the sea-line; from which it rose with seeming effort, like a heavy seabird, as night grew into morning. It was thus that most of us gained the midnight sun for the first time, not to lose it again until our approach to Norway in returning.

During the last day of July we pounded northward under a cloudy sky, with a touch of ice in the air; but in the evening we ran into sunshine again, and there, ahead of us, lay Bear Island miraged on the horizon. This was indeed good fortune, for in his eleven previous voyages past the island our Director had seen it only twice, so frequent are fogs in these seas. Our course was altered that we might run in under its eastern face. The placid sea around us was furrowed by its myriad sea-fowl, and from II p.m. until 2 a.m. we coasted its lonely cliffs and sea-stacks closely enough to distinguish the main features of their geological structure, and to catch glimpses of its desolate interior with all features accentuated by the light and shade of the low sun.

In its stratigraphy Bear Island is akin to Spitsbergen, though with a more restricted range of formations. To all geologists these far northern islands are of great interest, but peculiarly so to the geologists of Scandinavia, inasmuch as they contain a great sequence of the later Palæozoic, Mesozoic, and Tertiary sediments which are lacking within the Scandinavian 'shield.' To the Swedish explorers, and especially to Prof. J. G. Andersson, we owe most of our knowledge of the geology of Bear Island. At its southern extremity is a ridge of crushed and altered 'Heklahoek' rocks, which include fossiliferous Lower Silurian limestones. The rest of the land is built up of Devonian, Carboniferous, and marine Triassic strata, all in some parts very fossiliferous, and with coal seams in the Devonian. The sequence is interrupted by strong unconformities and broken by faults, some of which we could see plainly from our steamer.

Now it became difficult to chop up the Arctic day into conventional night and morning, and we counted by events - particularly by meal-times, for we were a hungry crew -rather than by the clock. Not many hours after sinking Bear Island in the southward, on August $I$, we began to meet floe-ice; which soon thickened, so that we had to slow down and eventually to turn southward and westward for more open water. Again and again during the day was this experience repeated, a chilly ice-blink always paling the hazy sky to the north and east as we threaded our zigzag course amid the floes, on which inquisitive seals shifted uneasily, doubtful whether to regard us as dangerous or not. Usually at this season the voyage to Spitsbergen lies entirely in open water; but most of us were glad of the chance which gave us this touch of the true Arctic colour. Still, to the anxious captain of our ship the prospect must have been decidedly less enjoyable. Thus we steamed cautiously all day and all night among the floes or along the broad water-lanes between the great white streaks drawn out by the north-flowing 
current, until we had been shouldered off 70 or 80 miles to the westward of Spitsbergen. On August 2, however, we got an easterly course, picking our way across the ice-streams where they were thinnest, and by evening the lead showed that we were approaching land. So we lay to, in a light haze, to await clear weather.

Soon, very gently, the haze thinned away; the northern sun shimmered again over the smooth olive sea, burnishing the floes into silver; and then, gradually, an exquisite panorama of peaks and glaciers was unveiled in front of us, lengthening northward and southward into a far perspective, and we knew that this was Spits-bergen, and worthy of its name. Due north of us rose the angular ridges of Prince Charles Foreland, and right ahead lay the gap of our haven, Ice Fiord; so we moved quietly forward, through a scene of dreamy splendour, to our anchorage after midnight in Safe Bay. Surely never was there a more impressive revelation of this silent land!

From this time onward our days were busy days, thronged with scientific interests and impressions that shifted all too rapidlv. Within the great Ice Fiord, which

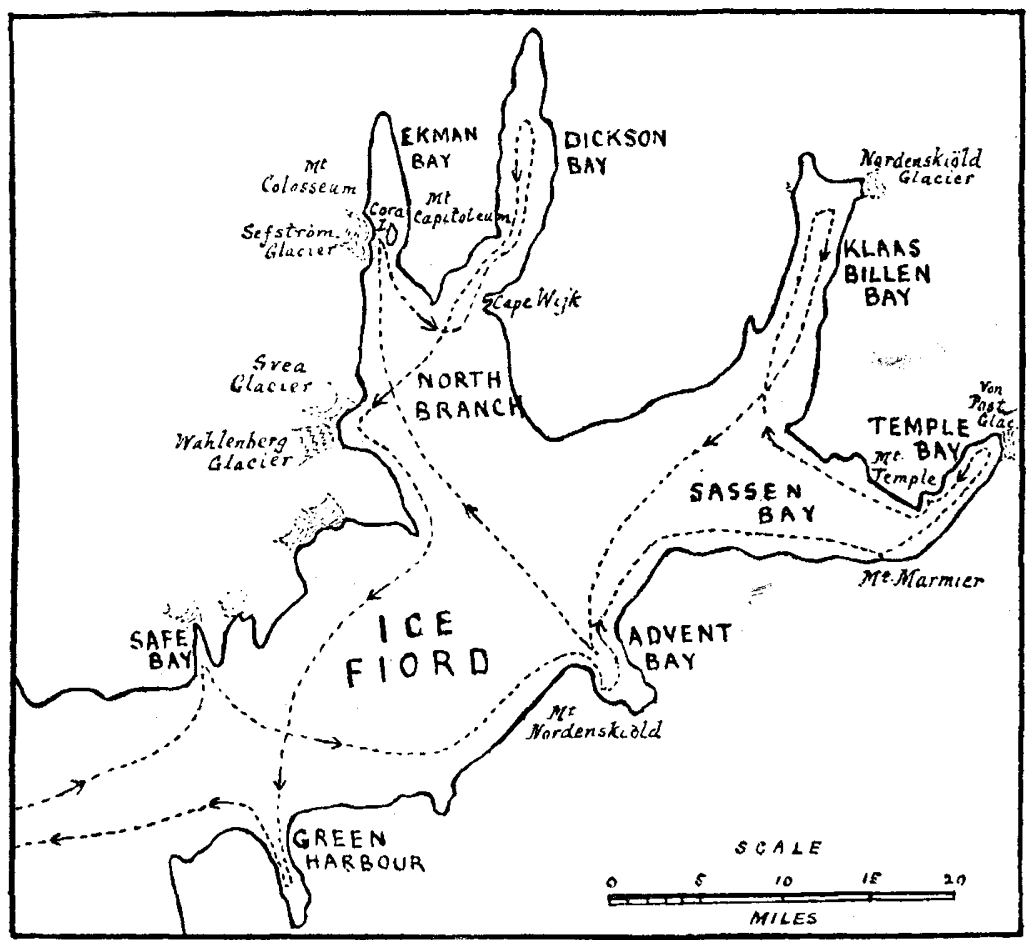

FIG. I. - Index-map of Ice Fiord, Spitsbergen. The course of the ss. Eolus is shown approximate'y by the dotted line.

runs for 60 miles eastward, crossing the strike of the rocks and almost bisecting the island, we found open water, and our ship was able to pass into all its branches without impediment. During the ensuing week we penetrated most of its recesses, landing at the best points for investigating its several formations, and gaining a clear idea of their structures from the barren craggy outcrops that rose high above all the waterways. (See Fig. I.)

Though complex in detail, the geology of central Spitsbergen is simple in its main outlines. Earth-movements of intensity, repeated at intervals down to Tertiary times, have ridged up the western margin of the island, bringing to light the oldest rocks and crumpling them along with the newer formations. These earth-waves, with their faults, folds and overthrusts, subside eastward, leaving a high plateau of regular stratigraphy and gentle dips, which is sharply trenched by the branching fiord and its tributary valleys. On the north side of the fiord most of the valleys contain glaciers which reach the sea; but on the south side, owing to difference of aspect and other causes, the land-valleys are often empty nearly to their heads.
The high jagged outer ridge, at the entrance to Ice Fiord, consists of crumpled Heklahoek rocks, succeeded eastward in the next ridges by sharply folded and broken Carboniferous strata. But in the interior, the long northern branches of the fiord reveal a great mass of red Devonian rocks, very similar to our British Devonian, upon which the Carboniferous strata rest with strong unconformity and overlap. In upward succession, the Carboniferous limestones and cherts are followed by a belt of sandstones and shales, to which, on the somewhat scanty fossil evidence, a Permian age is assigned; and above these come the Triassic strata, chiefly shales or clays, with thin limestones, sandstones, and phosphate-bands, often rich in wellpreserved marine fossils. The outcrops of the three lastmentioned formations are narrowed to strips in the outer folded belt, but expand into wide tracts around the interior fiord. Then follow thick masses of the Jurassic and Tertiary sediments, for the most part gently dipping and in apparent, but unreal, conformity, which build up the high picturesque plateaus on the south side of the inner fiord. These consist mainly of sandstones and shales of fresh-water or estuarine origin, but with occasional bands containing marine fossils. Both formations yield abundant well-developed plantremains, in striking contrast with the present diminutive Arctic flora; and both include coal-seams, at least one of which, in the Tertiary rocks, is likely to be of economic consequence.

To resume the recital of our doings in this land. We were astir early on the morning of August 3, anxious to take our first steps in Spitsbergen, and before breakfast many of us were ashore among the mixture of rocks, moraines, glaciers and raised beaches that forms the west shore of Safe Bay. Leaving this anchorage at breakfast time, our ship went east across Ice Fiord and ran close in under the bold precipices of Jurassic and Tertiary rocks bounding the plateau around Mount Nordenskiöld, until Advent Bay was reached, before noon. This has recently become a place of permanent habitation - the only one in the ownerless land. Most of us were surprised at the display of engineering activity in such a remote corner, brought about by American enterprise in the development of a mine in the Tertiary coal. A shipping wharf has been erected, to which the coal is brought from the mine high up on the hill-side by skips travelling overhead on a cable. At the mine, which we visited later, a seam of good quality, 4 feet thick, is worked by means of an adit. It was singular to see the walls of the workings all thickly encrusted with a sparkling layer of hoar-frost from the condensation of moisture on rock-surfaces that are permanently below freezing point. A pure white coal-mine!

For the afternoon in Advent Bay we divided into two parties. Those who wished to study the Jurassic plantbeds crossed with the ship to the north-east side of the inlet under the guidance of our Director. The rest of us landed at the wharf and went inland towards Mt. Nordenskiold, led by Mr. B. Hogbom, who had been already for some weeks in the island on geological work under Prof. De Geer's instructions, and who here awaited us. With him we went to the glacier-filled head of the valley south of the coal-mine and ascended the plateau on the westward to an upper moraine where Tertiary plant-fossils occurred in profusion. On this moraine, at an elevation of about 1500 feet, most of us were content to stay, basking in the sunshine and enjoying the glorious view over fiords, plateaus, and snow-fields; but certain of the more energetic elder members of our party continued upward 
over the snow to the very summit of Mt. Nordenskiold (346o feet), not reaching Advent Bay again until near midnight. The plateau which we traversed in returning to the ship was tesselated in places with fine examples of the singular "gardens" due to soil-creep-round or polygonal patches of clayey soil, up to 15 feet in diameter, bordered by slabs of stone, often on edge-which are remarkable in the Spitsbergen tundras at all levels, as in those of other Arctic lands.

Leaving Advent Bay at noon on August 4, our course was shaped eastward under the cliffs to Sassen Bay, where we made a short landing near Mt. Marmier to collect the abundant Triassic fossils and to examine the diabase which is here intruded conspicuously in sheets among the sediments. It was instructive to see how the shaly 'irias, very like our Lias in composition, was creeping down the slopes in big partly frozen mud-flows, mixed with ice and with blocks of diabase, providing a mass ready to be worked up by any advancing glacier into the semblance of our darker boulder-clays. This, indeed, is the particular value of the Spitsbergen phenomena to the English glacialist, that the country rocks are analogous in structure and texture to those of England, and are rarely of the hard type prevalent in nearly all other accessible regions of present-day glaciation.

Crossing Sassen Bay, we landed our palæontologists at Cape Bjona, under the fluted cliffs of Mt. Temple, for the collection of Carboniferous fossils from the inexhaustible stores of the limestones. The glacialists then went on with the ship to the head of Temple Bay, where the Von Post Glacier comes down to the sea with a front of ice-cliffs three miles broad. This glacier is now in retreat, and lateral moraines of its former extension line the fiord on both sides for a distance of more than a mile from the present front. Ice-falls from the glacier into the sea cause waves that have carved out cliffs 30 or 40 feet high in places, clearly revealing the composition of the moraines. These cliffs were strikingly similar to those of some English boulder-clays; indeed, but for the gleam of the neighbouring ice; one might have imagined oneself under a sea-cliff of north-east Yorkshire. The red loamy clay of the sections was studded, not too abundantly, with well-striated boulders of igneous and metamorphic rocks (from some unknown source beneath the glacier) along with others, more numerous, of grey and red sandstones, conglomerate, chert, Carbuniferous limestone, and other sedimentary rocks. Both moraines formed broad hummocky ridges, with troughs of lower ground behind them.

A party of five German explorers, . under the leadership of Lieut. W. Filchner, who were intent upon a journey into the interior of Spitsbergen, had been with us up to this point, interesting us greatly by the preparation of their outfit during the voyage. Now, with a heartening cheer, we left them to begin their adventures, our ship returning in the quiet evening sunlight for the night's anchorage at Bjona Harbour, where the impatient palæontologists hungrily declared that we were trying to starve them into glacialism!

Next day we coasted eastward to Klaas Billen Bay, and then northward up this deep inlet nearly to its head. A new phase in the stratigraphy of the island was here most instructively displayed in its bare brightly tinted slopes. Red Devonian strata rose up in strong force on its western side until unconformably overlain by the " Culm," which is believed to be of Lower Carboniferous age, while the limestones and cherts of the Upper Carboniferous rested in still bolder unconformity on both. A great fault cuts out the Devonian at the head of the bay; and east of it the Carboniferous rocks are known to rest directly upon bosses of an ancient complex group assigned to the Archæan, which we had not time to reach. Under the instruction of our leader these complicated features were made plain to us from the ship, and we realised how great was our advantage in gaining so comfortably in an hour the knowledge that would have cost many laborious days to gather without such guidance. Most of the day was spent on shore at the western side of the fiord; then, after a late dinner on the ship, we went to land again at Io p.m. on the eastern arm, for a midnight stroll to the Nordenskiold Glacier, which breaks off with a sea-front of three miles in water reaching nearly 500 feet in depth.
Under an overcast sky, which intensified the cold blueness of the ice, we crossed the tesselated tundra with its shelly terraces of raised beach to the southern moraine of the glacier, and saw how the grey shelly mud had been incorporated with the moraine. This was our coldest night, witn no sun; but we were fortified by a camp-fire on the beach, and hot coffee, before returning to the Eolus at 2 a.m.

An incident of navigation had rendered it necessary that our ship should return to Advent Bay for a further supply of coal, so now she went southward across Ice Fiord to the coaling wharf, and lay there during August 6 . Here, for the day, our party broke up into independent groups, some climbing the high plateaus, others going up the coalmine valley to the glaciers, and the palæontologists working assiduously along the Jurassic and Tertiary outcrops on the slopes above the bay. Next morning we left Advent Bay again for the North Branch of Ice Fiord, passing from cloud and breeze into bright still sunlight, with that local incidence of weather which appears to be characteristic of Spitsbergen, for all day we could see the cloud-banks pouring in like great glaciers from the ocean and welling up against the southern shore of the fiord.

Entering Ekman Bay, we passed along under the icecliffs of the Sefström Glacier, and anchored at a spot which quite recently was beneath the glacier. Above us, on opposite sides of the bay, rose the exquisitely fretted edges of Mt. Colosseum (1960 feet) and Mt. Capitolium (2790 feet), built up of nearly level Carboniferous rocks in tier after tier of belted crags, separated by high-pitched slopes and notched with amazing regularity by gullies and talus-cones (Fig. 2). We had seen similar features again and agai 1 during previous days, but here the sculpturing attained its greatest beauty, and the rhythm of light and shadow under the low sun gave a well-nigh perfect impression of architectural design. It was just the typical sculpturing of an arid climate, reminding us of scenes in the 'Bad Lands' and cañons of western America. In Spitsbergen, also, there is not sufficient precipitation to maintain permanent streams except those that have their source in melting snow and ice, so that the cones of frostriven talus everywhere accumulate on the bare slopes above the over-deepened main valleys.

As for the Sefstrom Glacier, it afforded us a series of lessons of surpassing interest. When first mapped by Prof. De Geer in I882, the sea-front of this glacier lay two or three miles back within its side-valley, and was flanked on both sides by fluvio-glacial outwash plains. Between that time and 1896 , when it was again examined by our Director, it had advanced about four miles, burying the outwash plains, filling its valley up to the mountain slopes, and bulging out into Ekman Bay in a broad lobe that reached across to Cora Island, hardly a mile from the opposite shore of the bay. But its spurt was over; already in 1896 it was sinking back; and when visited in I908, though its detached snout still hung grounded on Cora Island amid huge masses of morainic material, the main front had so far receded that there was again a sea-passage between it and the island, and a narrow strait, with ice-cliffs to right and left, between the new front and the detached portion affixed to the island. Since then there has been further recession, so that we found a wider passage; but a remnant of the melting snout still shone up conspicuously amid the red moraine on Cora Island.

We spent most of the day on the island, and I know that here was at least one glacialist of the party who felt that the time of the whole journey would have been well spent for the sake of this day alone! In its origina condition Cora Island was a low spit about two miles long and half a mile or more wide, composed of Carboniferous limesto ne partly covered with raised beach; but it has been increased to more than twice its size by the moraine banked upon its western side during its invasion by the glacier. This moraine, which for the greater part must have been actually under the ice at its maximum, has been thrown in a tumultuous succession of ridges and hollows across the flank of the island, forming a curved belt about three miles long, nearly half a mile wide at its broadest, rising in places to 50 or 60 feet above sea-level, and ending sharply, where it touches the original island, 
against the lower bare ground, with hardly any 'outwash' (see Fig. 3). It consists almost entirely of streaky red clay containing a few scratched boulders, and crowded with marine shells, some broken, but mostly perfect and the bivalves united. The clay has evidently been derived in the first place from the red Devonian rocks into which the fiord is cut; but its more immediate origin was the neighbouring sea-bottom, which has undoubtedly been dragged up in some way by the glacier in its advance. The existing remnant of the glacier was seen to be curiously entangled among the clay; and the presence of smaller masses of ice buried under the moraine was indicated by the crater-like hollows of subsidence by which its surface was pitted.

But the story of Cora Island is too long for our space -we must leave it regretfully, in the same mood that we left it on the late evening of August 7 , to hasten back to our ship. On August 8 the Eolus carefully threaded the different temperament; the Svea, smooth, wcrn, and retiring; the Wahlenberg, known to have been recently aroused into activity, and jagged, fissured, and tumbling in the rapidity of its advance. On this coast, also, our Director pointed out to us the crumpled structure of the rocky ridges separating the glacier-basins-huge wrinkles on the fringe of the western belt of disturbance. Crossing Ice Fiord once more, we found anchorage for the night in Green Bay, but not too near the malodorous whaling station, where the carcases of a dozen unshapely monsters awaited dismemberment.

On the morning of August 8 we landed on the west shore of Green Bay, and went inland up a transverse valley which cuts the mountainous ridge and very clearly reveals its structure--a steeply dipping succession of Carboniferous, Permian and Trias, with Jurassic on the shores of the bay, and Tertiary, comparatively undisturbed, above the eastern side. Mist, with a splutter of rain, hung around

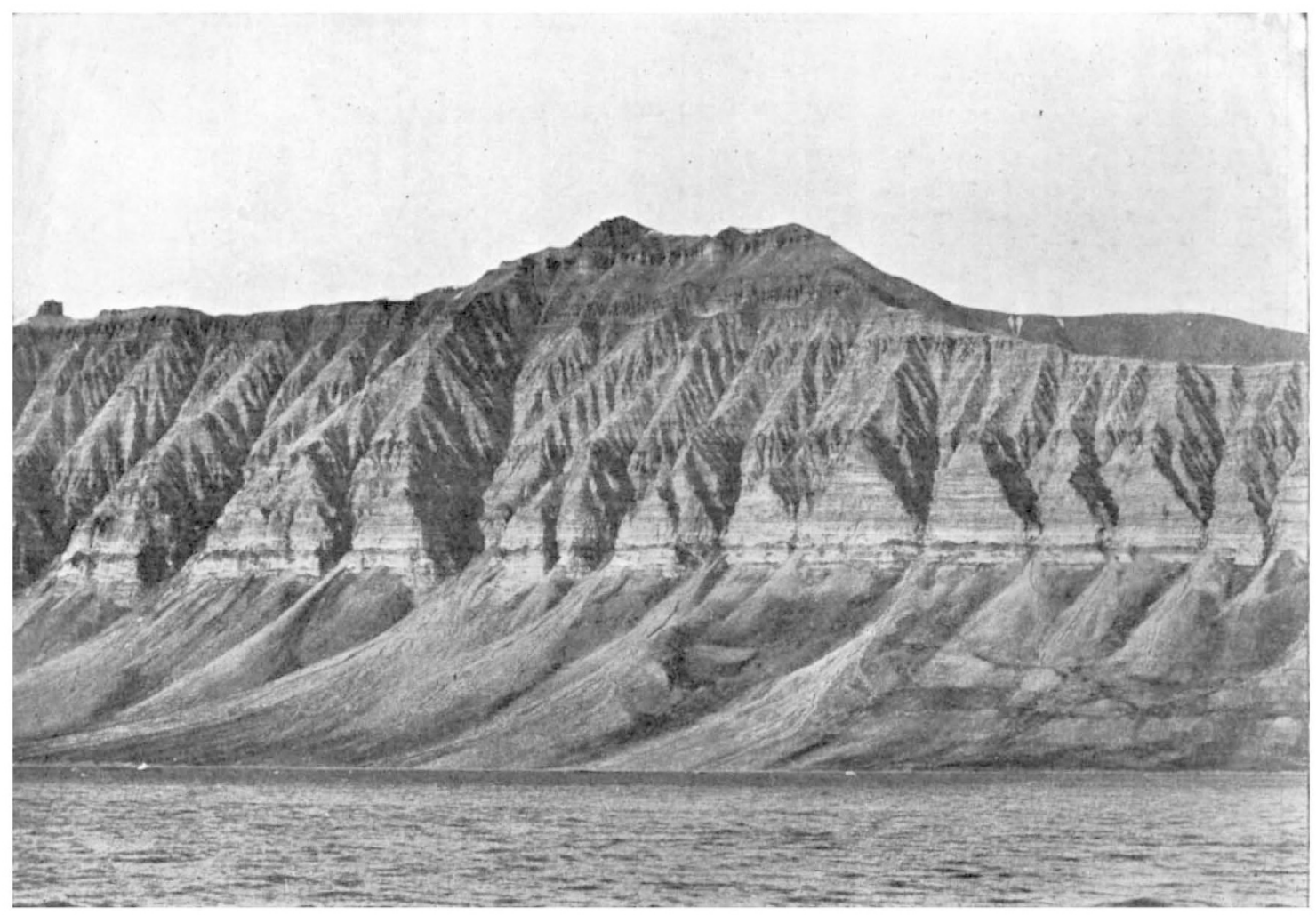

Photo. ly Oscar Halldin, Stockholm.]

[Reproduced by kind permission of Prof. G. de Geer.

FIG. 2.-Mount Capitolium (2790 feet), Ekman Bay. Carboniferous rocks (with underlying Devonian concealed by talus), showing fretted form developed by weathering.

inner recesses of Dickson Bay, where her farthest north, $78^{\circ} 50^{\prime}$, was reached, and where the glowing redness of the Devonian rocks - in the distance like heather in bloom - gave warmth to the Arctic wilderness. Many of us, however, chose the alternative of a landing under Cape Wijk, at the entrance to the fiord, and a long climb up the shaly slopes of Permian and richly fossiliferous Trias to the plateau at about 2000 feet, formed by an intrusive sill of diabase. There, in bright sunshine, we gained a view from which not all the promised reptiles of the Trias could drag us-fiords, glaciers, and valley-trenches everywhere around; away in the north-east, snowfields and peaks above the head of Wijde Bay; and our ship a speck on the blue floor of the nearer recess. Nevertheless, it would be a desolate land to be alone in with no such speck!

That same evening, in going southward, we steamed close in under the ice-cliffs of the Svea and Wahlenberg glaciers-contiguous neighbours, but at present of very NO. 2 I 44 , VOL. 85$]$ the peaks all day, but the valley was dry. Later, a fiving visit was made to the whaling station by those who could face the ordeal; and in this manner was our programme for Ice Fiord brought to its appointed end. As our ship swung westward into the floes at the mouth of the fiord the evening sunlight glittered on the land, just as it had done at our approaching; so it chanced that our last view of Spitsbergen was like our first.

It had been planned that we should visit Hornsund next day in returning southward. But the ice-floes drove us westward even farther than before, and there would have been much risk in pushing landward through them again. Our journey to the lonely island was done. So, after a few hours of devious sailing, we emerged from the tangle into the open ocean, and there rolled uncomfortably southward under a cold thick sky for the next two days, gaining the welcome shelter of the Norwegian coast on the morning of August 12. It was on the previous night that we'had reached into sunset again. 
Being now a few hours ahead of time, our captain took us up the lovely Lyngen Fiord, in glorious weather, with a sprinkle of new snow on all the peaks. Thus were we reconciled to the loss of Hornsund. And at Tromso in the afternoon we returned to the world of telegrams, letters and newspapers.

Of the after-voyage through the fiords to Trondhjem it is enough to say that the weather remained perfect; and that Dr. Hans Reusch, the Director of the Norwegian Survey, was of our company, so that we missed nothing that could be learnt in passing. At Trondhjem, moreover, on August I4, we had time, under Dr. Reusch's guidance, to visit the high strand-lines near the city and to examine the scientific and artistic collections in its museums, finishing the day with a pleasant reunion at one of the hotels. Here we left our ship, taking train on the morning of August ${ }_{5}$ up the fine valley that leads across the Swedish frontier. We reached Are in Jämtland in the afternoon, went eastward until evening across the ground we had seen from the summit of Areskutan, past the great Lake Storjon, and reached Stockholm, exactly on time, before breakfast on the morning of Wednesday, August 17. The initial reception of the members of the congress was held in Stockholm on the evening of that day.

To those who did not share in the pilgrimage this recital of our itinerary can at the best convey only a feeble idea of its advantages. Not the new country alone and the new experiences, but above all, the constant association and intercourse of men of different nationalities and outlooks, with interests in common which they were ever ready to discuss together-this it was that gave peculiar value to the journey, as to all journeys of the same type. Deeply indeed were we indebted to our leader, Prof. G. De Geer, and to the accomplished lady, his wife, for the whole-hearted enthusiasm which they threw into the difficult task of planning, guiding, and demonstrating in

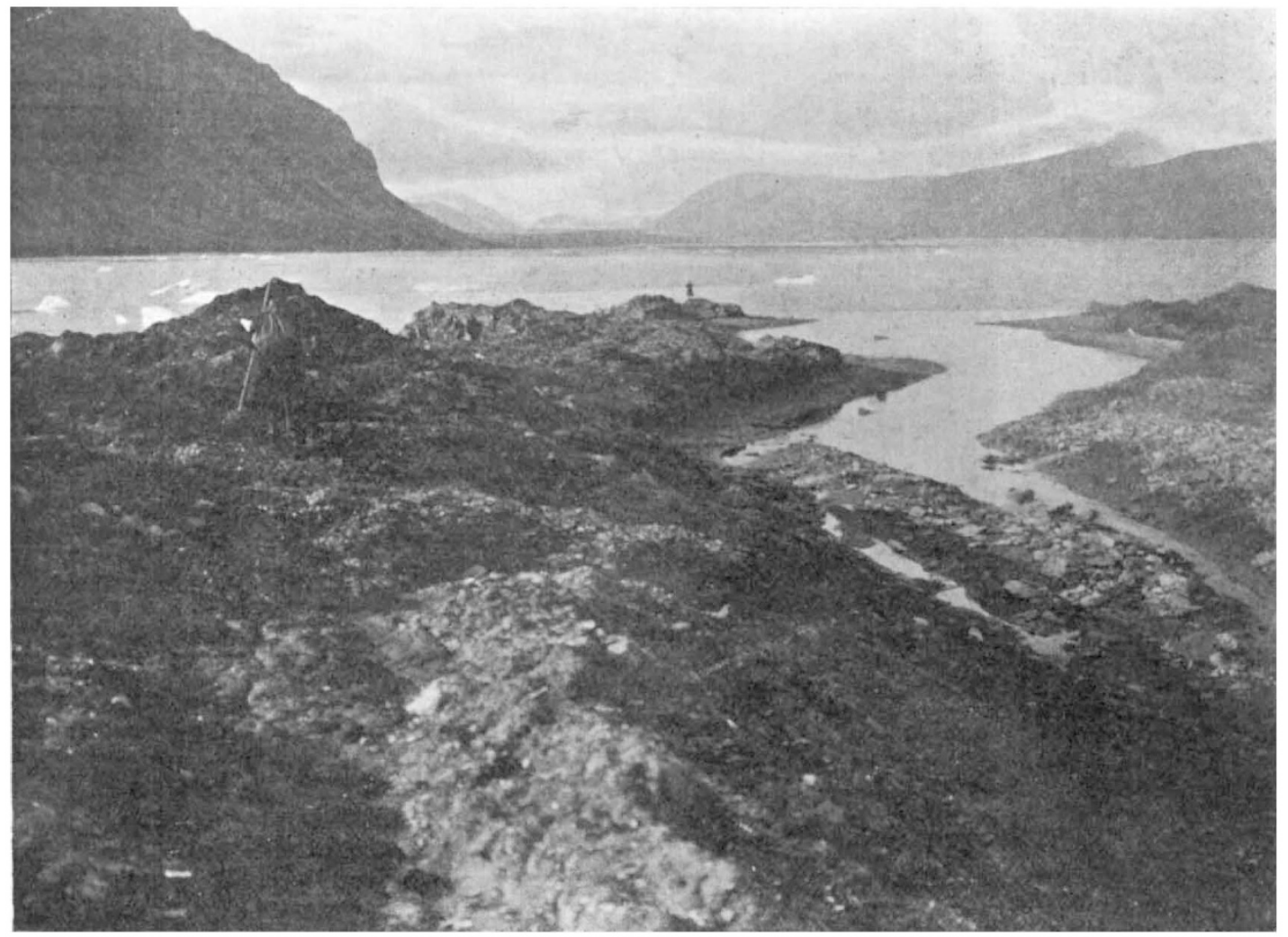

Photo. by Oscar Halldin, Stockholm.]

[Reproduced by kind permission of Prof. G. de Geer.

Fic. 3.-North end of Cora Island, Ekman Bay ; showing the Sefström moraine of shelly clay, to the left of the inlet, and a portion of the original island to the right.

in time to make the ascent of Mt. Areskutan ( 4620 feet) for the sake of the view from its summit over an immense range of lower lake-country to the eastward. The glacial phenomena of this region are like those of Tornetrask on a grander scale; the same evidence for a succession of glacier-dammed lakes, at first discharging westward over the watershed into Norway; the same shrinkage of the ice-sheet from the western mountain-rim to the lower eastern country; the same westward transport of the boulders. On the top of Areskutan there are boulders which have come from places far away to the eastward at much lower altitudes.

In the evening Prof. C. Wiman joined us at Are; and next morning, under his leadership, we visited sections near the Are Lake, which show the fossiliferous Lower Palæozoic succession. We were able also to appreciate the evidence for a gigantic overthrust of the metamorphic rocks from the westward over the unaltered Palæozoics. Leaving Are by train in the afternoon of August 16 , we varied languages so that the time at our disposal should alwavs be profitably spent; and even still more for the happy spirit of friendliness and geniality which they imparted to the whole expedition. Much also we owed to Mr. B. Hogbom for his share in the direction of our party in Spitsbergen, and to $\mathrm{Dr}$. $\mathrm{Hj}$. Lundbohm, Prof. C. Wiman, and Dr. O. Sjögren for their aid in Sweden, while $\mathrm{Mr}$. C. Carlzon and Mr. H. Ahlmann were our everobliging helpers and interpreters. In our admiration for the extraordinary skill with which every stage of the journey was arranged, we could not fail to recognise the thoughtful solicitude of our physician and treasurer, Dr. $J$. W. Nordenson, of whose high qualities as an organiser we had daily proof.

Brief must be our reference to the constitution of the party. The British geologists were lamentably fewG. A. J. Cole, A. P. Coleman, A. Strahan, and the writer -but, for the occasion, we will count with us a1so the U.S. Americans, R. S. Tarr, Miss F. Bascom, Miss Z. Baber, and Miss E. Rice. The German and Austrian 
contingent was predominant, including (titles omitted) H. Credner, G. Gürich, K. Keilhack, A. Penck, A. Rothpletz, W. Salomon, K. Sapper, F. Wahnschaffe, and other well-known names. Among those from France were L. Carez, L. de Lamothe, E. de Margerie, and A. Offret; from Italy, S. Cerulli-Irelli and E. Mattirolo; from Portugal, J. Mendez-Guerreiro; from Switzerland, M. Allorge, J. Brunhes, and P. Mercanton. From Denmark, among others, came V. E. Hintze, V. Madsen, and J. P. J. Ravn ; from Holland, J. I. J. M. Schmutzer and Mlle. A. Grutterink; from Norway, $H$. Reusch; from Hungary, E. de Cholnoky and E. de Maros; and Japan was represented by $K$. Inouye and H. Yabe. Broadcast now is the gathering that went with the good ship Eolus on this memorable voyage to Spitsbergen!

G. W. Lamplugh.

A FOURTH RECALESCENCE IN STEEL. 1 the recalescence points now known as $\mathrm{Ar}_{3}$ and $\mathrm{Ar}_{2}$,
and in 1872 Prof. W. F. Barrett, F.R.S., discovered the
$I^{N}$ I 868 the late Dr. George Gore, F.R.S., discovered

made possible by a gift of chemically pure iron from Dr. Hicks and Prof. O'Shea, of Sheffield University. The recalescence data registered in vacus on placing the thermocouple between two small plates of this iron show that the maximum of $\mathrm{Ar}_{3}$ appears at $854^{\circ} \mathrm{C}$., and the set-back between the two peaks of $\mathrm{Ar}_{2}$ is registered at $750^{\circ} \mathrm{C}$.

\section{The Recalescence of Iron containing about 0.2 per cent.} Carbon.

On cooling unsaturated steels containing about 0.2 per cent. carbon it was noticed that there was along the range of temperature between $\mathrm{Ar}_{3}$ and $\mathrm{Ar}_{1}$ some thermal evolution which prevented the curve crossing the radiation line after recalescence, and also kept it well to the right of that line. Careful investigation of this phenomena revealed the fact that whilst with iron containing 0.38 per cent. carbon this new and prolonged recalescence was very much augmented, as compared with a 0.2 per cent. carbon steel, that iron containing 0.63 per cent. carbon gives out during this fourth phase of recalescence much less heat than the 0.38 per cent. carbon steel. Therefore it would appear that the maximum of heat of the fourth phase of recalescence is evolved from a semi-saturated steel, namely, an iron containing 0.45 per cent. carbon, and having in the cold a micro-structure consisting of 50 per cent. ferrite and 50 per cent. pearlite. The recalescence data and curves of all these steels were shown on the screen and minutely described.

\section{The Cause of the Fourth Phase of} Recalescence.

By micro-thermal investigations Prof. Arnold has satisfied himself that the fourth phase of recalescence is due to constitutional segregation, namely, the falling out between $\mathrm{Ar}_{3}$ and $\mathrm{Ar}_{1}$ of the ferrite and hardenite from their state of mutual interpenetration or solid solution into microscopically invisible masses. A method was adopted for rapidly quenching from nitrogen in iced brine 0.2 per cent. carbon steel at various temperatures. The temperatures were:(1) $995^{\circ} \mathrm{C}$. (well above $\mathrm{Ar}_{3}$ ); (2) just below $\mathrm{Ar}_{3} ;$ (3) just after first peak of $\mathrm{Ar}_{2} ;$ (4) just above $\mathrm{Ar}_{1}$; (5) $\mathrm{I}_{5}^{\circ}$ (normalised or cooled in air)

The micrograph here reproduced is a section quenched between the two peaks of $\mathrm{Ar}_{2}$. The segregation is obviously proceeding very quickly, and the ferrite is strongly electro-negative to the dark etching areas of hardenite still containing in solution large quantities of iron. The micrographs indicate that the critical range $\mathrm{Ar}_{2}$ has no influence on the segregation of hardenite and ferrite. In Prof. Arnold's view these five photomicrographs, when correlated with the recalescence curves of the steel experimented upon, prove that the fourth phase of recalescence is due to the heat evolved between Pure Iron containing $0: 2$ r per cent. Carbon. Rapidly quenched between the two peaks of $\mathrm{Ar}_{2}$. Magnified 450 diameters.

point $\mathrm{Ar}_{1}$, which is now known as the carbon change point. Prof. Barrett gave the phenomena the generic title of "recalescence," by which they have been known ever since.

At the recent meeting of the British Association, Prof. J. O. Arnold described to the section of chemistry the result of accumulated thermal and micrographic observations upon this subject extending over twenty years. $\mathrm{He}$ first described the recalescence apparatus used at Sheffield University, in which the tape results can be plotted either as a time-temperature or as an inverse-rate curve. The latter is more delicate, its coordinates being units of temperature and time in seconds, for units rise or fall in temperature.

The Recalescence of Chemically Pure Iron.

From many observations it appears that before even a rough quantitative measurement of recalescence in steel can be made it is very desirable to obtain a standard cooling curve of iron absolutely free from carbon; this was during the segregation of the ultimate micrographic constituents of steel, which began at $\mathrm{Ar}_{3}$ and incomplete at $\mathrm{Ar}_{1}$, during the cooling of unsaturated steels at a moderate rate, say $0.5^{\circ}$ per second.

\section{REPORTS ON IMPERIAL FOODSTUFFS.}

$W E$ have received No. 63 ("Gums and Resins") and No. 7 I " Foodstuffs") of the "Colonial Reports: Miscellaneous," comprising selected reports from the Scientific and Technical Department of the Imperial Institute. They refer to products, from British possessions, examined at the institute with regard generally to the possibility of their profitable cultivation or preparation in the districts concerned. The first report is a useful little monograph on gums and resins from the commercial and analytical point of view, with particulars of the colonial specimens examined. The chief matter of scientific interest in the paper on foodstuffs, namely, a summary of the 